\title{
Diagnosis and Control of Harpophora maydis, the Cause of Late Wilt in Maize
}

\author{
Ofir Degani*, Gilad Cernica \\ Tel-Hai College, Upper Galilee, Israel and Migal, Galilee Research Institute, Kiryat Shmona, Israel \\ Email: *d-ofir@bezeqint.net, ofird@telhai.ac.il
}

Received November 9, 2013; revised December 9, 2013; accepted December 16, 2013

Copyright (C) 2014 Ofir Degani, Gilad Cernica. This is an open access article distributed under the Creative Commons Attribution License, which permits unrestricted use, distribution, and reproduction in any medium, provided the original work is properly cited. In accordance of the Creative Commons Attribution License all Copyrights (C) 2014 are reserved for SCIRP and the owner of the intellectual property Ofir Degani, Gilad Cernica. All Copyright (C) 2014 are guarded by law and by SCIRP as a guardian.

\begin{abstract}
Late wilt, a severe vascular disease of maize caused by the fungus Harpophora maydis, is characterized by relatively rapid wilting of maize plants, before tasseling and until shortly before maturity. In Israel, the disease becomes a major problem in recent years. The pathogen currently controlled using varieties of maize has reduced sensitivity. In earlier work, we modified a molecular method for use as a diagnostic tool to evaluate the disease progress in field infested plants. Several fungicides suppressed $H$. maydis in vitro and in a detached root pathogenicity assay. Seedling pathogenicity assay enables us to identified $H$. maydis DNA in the host root and stem tissues 18 days after sowing in both susceptible and tolerant maize plants. Although the infested plants exhibited no wilt symptoms, their roots were significantly shorter in length. This seedling assay was used to demonstrate the suppressive effect of the fungicide Flutriafol on $\mathrm{H}$. maydis virulence. The method of assaying the pathogen in a series of trials starting in a plate assay, followed by a detached root and resulting in a seedlings pathogenicity assay, using molecular and morphological approaches could be generalized to other plant pathogens.
\end{abstract}

\section{KEYWORDS}

\section{Flutriafol; Fungus; Fungicide; Harpophora maydis; Late Wilt; Maize; Molecular Diagnosis}

\section{Introduction}

Late wilt, or black bundle disease, is a vascular wilt disease of corn caused by the soil-borne and seed-borne fungus, Harpophora maydis [1,2] W. Gams [3] with synonyms: Cephalosporium maydis Samra, Sabet, \& Hingorani and Acremonium maydis [4]. This disease was first reported as a vascular wilt disease of corn in Egypt in 1960 [5] and is now considered endemic throughout Egypt. Late wilt was also reported in India [6], Hungary [7], Israel [8,9], Spain and Portugal [10]. Serious economic losses from late wilt have been reported in Egypt, where $100 \%$ infection occurs in some fields, and in India, with an incidence as high as 70\% and economic losses up to 51\% [11]. Zea mays (corn, maize) and Lupinus (lupine) are the only known hosts of $H$. maydis, although localized lesions occur on young cotton hypocotyls (Bahteem

\footnotetext{
"Corresponding author.
}

185 cultivar). These lesions disappear as the cotton plants mature and $H$. maydis has not been recovered from them [12]. H. maydis causes a significant damping-off and stunting of the widely cultivated Lupinus terminis in Egypt [13]. The fungus is considered as a distinct species within the Gaeumannomyces-Harpophora complex [14]. The Egyptian, Indian and Hungarian isolates of $H$. maydis differ in morphology, pathogenicity and route of infection [15]. The four clonal lineages of Egyptian isolates of $H$. maydis show diversity in amplification fragment length polymorphism (AFLP), and differ in colonization ability and virulence on maize [16-19]. Three of the lineages are widely distributed throughout the country. The fourth lineage was the most virulent but least competitive on susceptible maize accessions when inoculated as a mixed inoculum of all four isolates [18].

Late wilt disease is characterized by relatively rapid wilting of maize plants, typically at the age of 70 to 80 
days, before tasseling and until shortly before maturity. First symptoms appear approximately 60 days after sowing [20] and include the development of light green stripes on the leaves; the stripes become translucent, and the entire leaf rolls inward from the edges. Later, drying-out ascends upwards in the plant and includes leaf yellowing and dehydration, color alteration of the vascular bundles to a yellow-brown hue and then the appearance of redbrown stripes on the lower internode, the symptoms advancing to the fifth internode or further [12]. With disease progression, the lower stem dries out (particularly at the internodes) and has a shrunken and hollow appearance, with dark yellow to brownish macerated pith and brownish-black vascular bundles. Late wilt is often associated with infection by secondary invaders such as $H$. acremonium, Sclerotium bataticola, Fusarium verticillioides and various bacterial rots to present a "stalk rot complex" [4, 21]. These saprobic organisms cause the stem symptoms to become more severe. Fewer ears are produced, and kernels that form are poorly developed [9] and may be infected with the pathogen. Seed quantity is correlated negatively to disease severity [22]. Payak et al. (1970) reported that the fungus caused seed rot and a low percentage of emergence, and plants that did emerge were delayed [6]. These researchers also reported that seeds taken from infected plants showed similar symptoms. In severe cases, no cobs were formed.

Samra et al. [21,23] isolated the pathogen from maize roots, stems and cobs, and identified it as Cephalosporium maydis. In 1971, based solely on the morphology of the culture, the pathogen was excluded from the confused genus Cephalosporium and was recognized as being related to Gaeumannomyces [3]. In 2000, Gams introduced the genus Harpophora and transferred the species to this genus. In 2004, the pathogen was confirmed as a distinct species in the Gaeumannomyces-Harpophora species complex [14]. H. maydis reproduces asexually, and no perfect stage has been identified [19].

$H$. maydis survives as sclerotia on corn debris and infects seedlings through the roots or mesocotyl. Optimum temperature and moisture conditions for corn growth also are optimal for disease development [15]. Thus, late wilt develops rapidly at $20^{\circ} \mathrm{C}-32^{\circ} \mathrm{C}$, with optimum disease development at $21^{\circ} \mathrm{C}-27^{\circ} \mathrm{C}$ [24]. Growth of $H$. maydis in soil is sharply inhibited above $35^{\circ} \mathrm{C}$, but this fungal pathogen can grow over a wide range of soil $\mathrm{pH}$ from 4.5 - 10, with an optimum at pH 6.5 [25]. Spread is primarily through movement of infested soil, crop residue, or seedborne inoculum. Spread within a field is often associated with mechanical operations such as cultivation that moves soil. H. maydis can persist on corn stubble for 12 - 15 months $[20,25]$. Sclerotia are produced under low humidity, which ensures long-term survival of $H$. maydis (up to 15 months) in no-till residues on the soil surface. Lu- pine facilitates parasitic survival of the pathogen under at least some field conditions $[11,26]$. $H$. maydis can survive in seeds for 10 months at high temperatures and low humidity in India, but longer survival is predicted at low temperatures [24]. Infected seeds can produce plants with late wilt symptoms, infest soil and result in subsequent development of late wilt in healthy seeds grown in that soil.

The most effective control of late wilt is using resistant germplasm [19,27], although some cultural and chemical controls can reduce its impact on commercial production. The National Maize Program at the Agricultural Research Center in Giza, Egypt identified many sources of resistance through their screening of thousands of local and exotic germ lines since 1963. Their release of resistant varieties since 1980 has significantly reduced late wilt losses in Egypt [27]. In Israel, a breeding program for resistant germ lines has existed for about a decade (Israel Northern R \& D, Migal-Galilee Research Institute, Kiryat Shmona, Israel, unpublished data).

Various cultural measures such as soil solarization, balanced soil fertility and flood fallowing can reduce disease severity and losses. Inoculum survival is restricted to the top $20 \mathrm{~cm}$ of soil, and survival depends primarily on the persistence in infected crop residues [28]. Moisture management and flood fallowing may be useful cultural controls for late wilt where they are economically practical $[2,29]$. Balanced fertility can reduce disease severity, although it does not provide complete control. Low levels of nitrogen fertilization (60 kg/ha) increased wilt [30] even though yields were increased overall; however, higher nitrogen levels (120 kg N/ha) needed for optimal yield reduced late wilt [30]. A physiological sufficiency of potassium is also reported to reduce late wilt in low K fields of India [30], but not in the higher K soils of Egypt [2]. Phosphorus, organic amendments (straw, cotton cakes, and brodret) and micronutrients $(\mathrm{Cu}, \mathrm{Fe}, \mathrm{Mn}$, and $\mathrm{Zn)}$ also reduce disease severity [30].

Many attempts were made to control the pathogen using chemical and biological methods [31-36]. Some fungicides that were tested worked well in pots but failed in field experiments [32], while others achieved promising success [32]. Since $H$. maydis is a poor saprophytic competitor [20], various attempts at biological control by inoculating corn seed with competitive or antagonistic organisms (Macrophomina phaseolina, Trichurus spiralis, Bacillus subtilis, Pseudomonas fluorescens, Verticillium tricorpus) have been evaluated [29,33,37,38]; however, success on a field scale has not been demonstrated consistently. Today, there is no available effective chemical or biological method for controlling late wilt in Israel.

Previously species-specific PCR primers capable of distinguishing $H$. maydis from other species in the $G a-$ 
eumannomyces-Harpophora complex were developed [14] and used as a diagnostic assay of disease progress in an infested field in northern Israel [9]. Here, we conduct a controlled inspection of selected fungicides in an in vitro plate assay, in detached roots and in seedlings. By using the DNA-sequence-based approach $[9,14]$, we studied the influence of these fungicides on the pathogenesis of $H$. maydis in seedlings in a growth room.

\section{Materials and Methods}

\subsection{Fungal Isolates and Culture Conditions}

Four isolates of $H$. maydis (called $\mathrm{Hm}-1, \mathrm{Hm}-2, \mathrm{Hm}-3$, $\mathrm{Hm}$-4, three of them now deposited in the CBS-KNAW Fungal Biodiversity Center, Utrecht, the Netherlands, under the numbers CBS 133164, CBS 133165, CBS 133166) were used in this study. These $H$. maydis strains were recovered from wilting maize plants (Zea mays L., Jubilee cv., Syngenta, Fulbourn, Cambridge, UK) sampled from a maize field in Sde Nehemia in the Hula Valley of Upper Galilee (northern Israel) in 2001. Pathogenicity of the Israeli $H$. maydis isolates was confirmed by complying with Koch's postulates, and the pathogen was characterized by its colony morphology and microscopic traits [9]. The morphological and microscopic characteristics of the pathogen were identical to those of previously described strains found in Egypt and India [6,23]. Final confirmation was achieved by PCR-based DNA analysis [9]. All isolates were grown on potato dextrose agar (PDA) (Difco, Detroit, MI, USA) at $28^{\circ} \mathrm{C}$ in complete darkness. To prepare inocula, 10 colony agar disks (6-mm-diameter each taken from the margins of a 5day-old colony) were added to a 200-ml Erlenmeyer flask containing $150 \mathrm{ml}$ of autoclaved sterile potato dextrose broth (PDB). Cultures were grown at $28^{\circ} \mathrm{C}$ in the dark on a rotary shaker at $150 \mathrm{rpm}$ for six days. The mycelium was harvested by filtrating it from the media, homogenizing it using a polytron homogenizer (Kinematica AG, Luzern, Switzerland) at low speed for $3 \mathrm{sec}$ and resuspending it in sterile double-distilled water (DDW) to a final concentration of 100 gr mycelia fragments $/ 200 \mathrm{ml}$.

\subsection{Maize Plants Growth Conditions}

Two representative maize cultivars were selected for the pathogenicity tests: the susceptible cultivar of sweet corn Jubilee and the relatively resistant cultivar Royalty from Pop Vriend Seeds B.V., Andijk, The Netherlands (both supplied by Eden Seeds, Reut, Israel). These varieties had been tested previously for susceptibility to late wilt (Israel Northern R \& D, Migal-Galilee Research Institute, Kiryat Shmona, Israel, unpublished data sited in [9]). Maize seeds were washed thoroughly (to wash off any remains of insecticide coatings) by rinsing them with water and soaking them with stirring in a large of volume of DDW for 16 hours. The seeds were surface sterilized by dipping them in $70 \%$ ethanol solution for 2 min followed by several rinses in sterile water. They were subsequently placed to germinate in $15 \mathrm{~cm}$ diameter sterile plastic petri dishes covered with wet (sterile DDW) Whatman 3MM filter paper or cotton-wool for two days at room temperature $\left(22^{\circ} \mathrm{C}-28^{\circ} \mathrm{C}\right)$ and ordinary daylight. Healthy germinating seeds were selected, and each seed was sown individually in a plastic seedling nine pot tray about $5 \mathrm{~cm}$ beneath the surface. The soil mix (Shacham Givat Ada, Givat Ada, Israel) was commercial, nonsterilized, composed of 65\% coco, 20\% peat, 10\% tuff (4 - 10 mm volcanic stones) and 5\% Multicote ${ }^{\circledR}$ (slow-release fertilizers, Pt. Multigreen Indonesia, Jakarta, Indonesia), w/w. Watering was done by adding $500 \mathrm{ml}$ DDW in twoday intervals to the plastic seedling pot tray. Each treatment was done in a separate tray. All the plants used for the detached roots experiment, the detached leaves pathogenicity assay and the seedlings pathogenicity assay were grown in a growth chamber under constant temperature of $30^{\circ} \mathrm{C} \pm 2^{\circ} \mathrm{C}$ and photoperiod conditions of 12 hours of light (from cool-white fluorescent tubes, Philips, Eindhoven, The Netherlands) and 12 hours of darkness. Maize seedlings were 21 days old unless otherwise indicated. Plants were used when the fourth leaf had emerged, remained partly rolled, and was beginning to expand.

\subsection{Detached Leaves Pathogenicity Assay}

Detached leaves were used to determine the ability of the pathogen to penetrate the plant through the surface of healthy or wounded leaves. This technique was described before [39] for Cochliobolus heterostrophus (C4 strain, MAT1-2 Tox $1^{+}$[ATCC 48331]) that was used here as positive control. C. heterostrophus was grown on a complete medium (CM) [40] for about six days at room temperature in continuous light from cool-white fluorescent tubes (Philips, Eindhoven, The Netherlands). Plants were used 17 days after sowing when the third leaf had finished emerging and was fully expanded. Each detached first leaf, except for the negative control, was inoculated in six locations across its upper surface, with 1-2-mm-diameter culture agar pieces cut from the margins of 4-6day-old $H$. maydis colonies. Additional treatment was done using wounded leaves. The leaves were pierced with a sterile wooden toothpick immediately before laying the culture agar piece at the injured location. The leaves were then incubated in a moist petri dish (lined with DDW wetted Whatman 3 MM filter paper) for three days at $28^{\circ} \mathrm{C}$ under continuous white light in a growth incubator. The severity of the disease progress was evaluated qualitatively. 


\subsection{Adaptation of Molecular Diagnosis}

DNA was obtained with the Extract-N-amp plant PCR kit (Sigma, Rehovot, Israel) according to the manufacturer's instructions from 7-day-old cultures grown under the above-described conditions. PCR was performed to amplify a specific $H$. maydis segment $[9,14]$ with a Rapidcycler (Idaho Technology, Salt Lake City, UT, USA). We modified an existing molecular assay [14] by choosing a new set of primers (A200a and Am42/43) using a different reaction mixture and altering the cycling condition as described below (adapted from [9] with modification in the primers selection). This new sequence is a major part of a larger AFLP fragment that was proven earlier to be species-specific $[9,17,19]$. The A200a primer set-[A200a-for (forward primer): 5'-CCTAGTAGTCCCGACTGTTAGG-3', A200a-rev (reverse primer):

5'-TTGGTTCACCGTCTTTTGTAGG-3'] amplifies a specific [14] H. maydis segment. The Am42/43 primer set [Am42 (anti-sense primer):

5'-CAACTACGAGCTTTTTAACTGC-3', Am43

(sense primer): 5'-CAAATTACCCAATCCCGACAC-3'] amplifies eukaryotic ribosomal DNA (18S rRNA gene product, rDNA, [41]) and was used for positive control. Reaction mixtures were contained in a total volume of 50 $\mu \mathrm{l}: 1 \mu \mathrm{l}$ of each primer (20 $\mu \mathrm{M}$ of each primer), $25 \mu \mathrm{l}$ Red Load Taq Master (Larova, Teltow, Germany), $3 \mu \mathrm{l}$ DNA sample and $20 \mu \mathrm{l}$ DDW. Cycling conditions for all primer pairs were $94^{\circ} \mathrm{C}$ for 2 min, followed by 35 cycles of $94^{\circ} \mathrm{C}$ for $30 \mathrm{sec}, 55^{\circ} \mathrm{C}$ for $30 \mathrm{sec}, 72^{\circ} \mathrm{C}$ for $1 \mathrm{~min}$, and a final step of $72^{\circ} \mathrm{C}$ for 5 min. After PCR, a 200-bp amplified DNA band was identified by electrophoresis on an Agarose gel. Ribosomal DNA (18S rDNA) [41] bands were used as positive control for the molecular procedure.

\subsection{Fungicide Efficiency Agar Plates Assay}

We carried out an in vitro evaluation of eight technicalgrade, commercial fungicides on the radial mycelial growth of $H$. maydis (Table 1). Isolates were inspected for fungicide sensitivity in growth assays on agar plates. The fungicides were evaluated at three to four rates $(0.1$, $0.5,1$ and $10 \mathrm{mg} / \mathrm{L}$ active ingredient, data presented only for the high, 1 and $10 \mathrm{mg} / \mathrm{L}$, rates). Since this is the first time that these fungicides were inspected against the Israeli $H$. maydis isolates, a manufacturer's recommendation rate was not available. The preparation of each fungicide stock solution was done by dissolving it in ethanol or DDW according to the manufacturer's instructions. The final concentration of the stocks was 100 $\mathrm{mg} / \mathrm{l}$. The stock solutions were filtered using a $0.2 \mu \mathrm{m}$ syringe filter (Danyel Biotech, Rehovot, Israel). Media for the inhibition-response experiments were prepared by adding the fungicides in the required concentration to an autoclaved PDA after it had cooled down to $55^{\circ} \mathrm{C}$.

Twenty milliliters of these PDA amended with different fungicide rates were poured into a $9 \mathrm{~cm}$ diameter petri dish. Each plate, including the control (without fungicide), was inoculated on solidification in the middle with a $6 \mathrm{~mm}$ (in diameter) culture agar disk cut from the margins of 4-6-day-old $H$. maydis colonies. Labeled petri dishes were placed in an incubator at $28^{\circ} \mathrm{C}$ in the dark. All treatments (fungicide at different rates and the control) were replicated six times. Radial mycelial growth was taken five days (unless otherwise indicated) after inoculation by measuring the diameter along two perpendicular lines from the underside of the petri dishes. Each experiment was repeated twice. Data collected were subjected to statistical analysis using the student's t-test.

\subsection{Detached Root Pathogenicity Assay}

An in vitro method was developed to determine the relative pathogenicity of $H$. maydis isolates on maize detached roots. Plants were grown as described above. For the selection of roots, care was taken to collect roots of similar diameter and pigmentation. The longest inner feeder roots were removed from potted 21-day-old maize seedlings (Zea mays L., Jubilee cv.) and washed in tap water to remove the soil. The roots were disinfected using $70 \%$ ethanol solution and dried in a pre-sterilized fume hood. Each root was then placed individually in a sterile plastic petri dish lined with Whatman 3MM filter paper. Selected fungicide $(10 \mathrm{mg} / \mathrm{ml})$ or DDW (as positive control) was added separately to each plate. A 6-mm-diameter culture agar disk taken from the growing edge of a 4-6-day-old fungal colony (grown at $28^{\circ} \mathrm{C}$ in the dark) was placed $2 \mathrm{~cm}$ away from the cut end of each root. Negative control roots had a sterile agar disk placed near the cut ends. C. heterostrophus was not used in the root pathogenicity assay as a comparison since it is dispersed by wind and/or splashing rain [42], so it is incapable of penetrating the host plants through the roots. The petri dishes were sealed with Parafilm (a plastic paraffin film) and incubated at $28^{\circ} \mathrm{C}$ in the dark. Each treatment was done in triplicate. The lengths of the root infection threads (seen as dark filament within the root) were measured six days after inoculation.

\subsection{Seedlings Pathogenicity Assay}

This assay was developed in two stages: first, we tested several infection methods in order to identify the most effective inoculation method. Then, we used the selected infection method to examine the ability of the pathogen to infect maize seedlings in the presence of the fungicide Flutriafol (CAS no. 87676-93-5, 10 mg/ml, Hosen, Makhteshim Agan, Airport City, Israel), which was found 
Table 1. Fungicides used in this study*.

\begin{tabular}{|c|c|c|c|c|c|c|c|}
\hline Fungicide & $\begin{array}{l}\text { Manufacturer, } \\
\text { Supplier }\end{array}$ & $\begin{array}{l}\text { Active Ingredient } \\
\text { (common name) }\end{array}$ & Group Name & $\begin{array}{l}\text { Chemical } \\
\text { Group }\end{array}$ & $\begin{array}{l}\text { Target Site of } \\
\text { Action }\end{array}$ & $\begin{array}{c}\text { Active } \\
\text { Ingredient } \\
\text { Concentratio } \\
\text { n (g/l) }\end{array}$ & $\begin{array}{c}\text { Efectiviness } \\
\text { in Agar Plate } \\
\text { Assay (10 } \\
\text { mg/L) }\end{array}$ \\
\hline Rodion ${ }^{\circledR}$ & $\begin{array}{l}\text { Agriphar (Ougrée, } \\
\text { Belgium), CTS } \\
\text { (Tel Aviv, Israel) }\end{array}$ & Iprodione & Dicarboximides & Dicarboximides & $\begin{array}{l}\text { MAP/histidine } \\
\text { kinases in } \\
\text { osmotic signal } \\
\text { transduction } \\
\text { (os-1, Daf } 1)\end{array}$ & 500 & - \\
\hline Terraclor ${ }^{\circledR}$ & $\begin{array}{c}\text { Amvac (Los } \\
\text { Angeles, CA USA), } \\
\text { Luxembourg } \\
\text { Industries Ltd. } \\
\text { (Tel Aviv, Israel) }\end{array}$ & $\begin{array}{l}\text { Pintachloronitrobenzene } \\
\text { (PCNB) }\end{array}$ & $\begin{array}{l}\text { AH-fungicides } \\
\text { (aromatic } \\
\text { hydrocarbons) } \\
\text { (chlorophenyls, } \\
\text { nitroanilines) }\end{array}$ & $\begin{array}{c}\text { Aromatic } \\
\text { hydrocarbons }\end{array}$ & $\begin{array}{l}\text { Lipid } \\
\text { peroxidation } \\
\text { (proposed) }\end{array}$ & 750 & + \\
\hline Octave ${ }^{\circledR}$ & $\begin{array}{c}\text { BASF } \\
\text { (Ludwigshafen, } \\
\text { Germany), Merhav } \\
\text { Agro Ltd. (Herzliah } \\
\text { Israel) }\end{array}$ & $\begin{array}{l}\text { Prochloraz present as } \\
\text { the manganese } \\
\text { chloride complex }\end{array}$ & $\begin{array}{l}\text { DMI-fungicides } \\
\text { (demethylation } \\
\text { inhibitors) }\end{array}$ & Imidazoles & $\begin{array}{c}\text { C14- } \\
\text { demethylation } \\
\text { in sterol } \\
\text { biosynthesis } \\
\text { (erg11/cyp51) }\end{array}$ & 462 & +++ \\
\hline Amistar ${ }^{\circledR}$ & $\begin{array}{c}\text { Syngenta } \\
\text { (Basel, } \\
\text { Switzerland), } \\
\text { Makhteshim Agan } \\
\text { (Airport City, } \\
\text { Israel) }\end{array}$ & Azoxystrobin & $\begin{array}{l}\text { QoI-fungicides } \\
\text { (quinone outside } \\
\text { inhibitors) }\end{array}$ & Methoxy-acrylates & $\begin{array}{l}\text { Complex III: } \\
\text { cytochrome bc1 } \\
\text { (ubiquinol } \\
\text { oxidase) at Qo site } \\
\text { (cyt } b \text { gene) } \\
\text { (inhibition of } \\
\text { mitochondrial } \\
\text { respiration) }\end{array}$ & 250 & +++ \\
\hline $\begin{array}{l}\text { Signum } \\
\text { W.G.® }\end{array}$ & $\begin{array}{c}\text { BASF } \\
\text { (Ludwigshafen, } \\
\text { Germany), } \\
\text { Agan (Ashdod, } \\
\text { Israel) }\end{array}$ & $\begin{array}{l}\text { 26.7\% Boscalid, } \\
\text { 6.7\% Pyraclostrobin }\end{array}$ & $\begin{array}{l}\text { SDHI (Succinate } \\
\text { dehydrogenase } \\
\text { inhibitors) } \\
\text { QoI-fungicides } \\
\text { (Quinone outside } \\
\text { Inhibitors) }\end{array}$ & $\begin{array}{c}\text { Pyridine } \\
\text {-carboxamides } \\
\text { Methoxy } \\
\text {-carbamates }\end{array}$ & $\begin{array}{c}\text { Complex II: } \\
\text { Succinate } \\
\text {-dehydro-genase } \\
\text { Complex III: } \\
\text { cytochrome bc1 } \\
\text { (ubiquinol oxidase) } \\
\text { at Qo site } \\
\text { (cyt b gene) }\end{array}$ & $\begin{array}{l}267 \\
67\end{array}$ & +++ \\
\hline Hosen & $\begin{array}{l}\text { Cheminova } \\
\text { (Lemvig, } \\
\text { Denmark), } \\
\text { Makhteshim } \\
\text { Agan (Airport } \\
\text { City, Israel) }\end{array}$ & Flutriafol & $\begin{array}{l}\text { DMI-fungicides } \\
\text { (demethylation } \\
\text { inhibitors) }\end{array}$ & Triazoles & $\begin{array}{l}\text { Disrupt C14- } \\
\text { demethylation } \\
\text { in sterol } \\
\text { biosynthesis } \\
\text { (erg11/cyp51) }\end{array}$ & 125 & +++ \\
\hline $\begin{array}{l}\text { Sportec/ } \\
\text { Mirage } 45 \\
\text { ECNA }\end{array}$ & $\begin{array}{l}\text { Merhav Agro Ltd. } \\
\text { (Herzliah Israel)/ } \\
\text { Makhteshim Agan } \\
\text { (Airport City, } \\
\text { Israel) }\end{array}$ & $\begin{array}{l}\text { Prochloraz/ } \\
\text { Prochloraz zinci }\end{array}$ & $\begin{array}{l}\text { DMI-fungicides } \\
\text { (demethylation } \\
\text { inhibitors) }\end{array}$ & Imidazoles & $\begin{array}{c}\text { C14- } \\
\text { demethylation } \\
\text { in sterol } \\
\text { biosynthesis } \\
\text { (erg11/cyp51) }\end{array}$ & 450 & +++ \\
\hline
\end{tabular}

* This information is based on the funguicides data sheet published by the manufactor and on the Fungicide resistance action committee (FRAC) Code List. ${ }^{* *}$ Indicates the significant difference from the control (growth media without fingicide)-insignificant, $+\mathrm{p}<0.05,++\mathrm{p}<0.005,+++\mathrm{p}<1 \times 10^{-5}$.

to be effective in inhibiting the fungus colony radial growth in an agar plate assay (see above). Seedlings of both the susceptible maize Jubilee cv. and the relatively resistant Royalty cv. were grown to the four-leaf stage (22 days after planting) in seedlings in plastic pot trays under the above-mentioned conditions. Seedling inoculation was done with sowing, four days after germination. The seedling inoculation inspection included two different infection methods: soil inoculation with mycelium inocula, or colony agar (PDA) disks. For soil inoculation, 
the fungi were grown in liquid medium as described above. The mycelium was harvested, and $10 \mathrm{ml}$ of 0.5 $\mathrm{gr} / \mathrm{ml}$ mycelium suspension were added to each plant by removing the ground near the seedling and adding the mycelium suspension directly to the upper parts of the roots ( 2 - $5 \mathrm{~cm}$ beneath the ground surface). Alternatively, we added three 6-mm-diameter agar disks from 6-dayold $H$. maydis colonies (grown on PDA at $28^{\circ} \mathrm{C}$ in the dark as described above) to the upper parts of the roots (2 - $5 \mathrm{~cm}$ beneath the ground surface). The control plants (non-inoculated plants) were grown under the same conditions. Each treatment included 10 independent replications. In order to identify the fungus in the host plant tissues, three representative plants (22 days old) from each treatment were sampled arbitrarily.

The whole plant samples (root, stem and leaves together) were sterilized separately with $70 \%$ ethanol and then washed with autoclaved DDW. The samples were ground separately in a mortar with pestle, and DNA was extracted immediately after harvesting and kept at $-20^{\circ} \mathrm{C}$ for later analysis. All DNA samples (each treatment was done in triplicate) were analyzed together as described above. Root length was determined as the average length of the longest root of each plant in 10 independent replicates of each cultivar. The experiment was repeated twice.

In a subsequent experiment, we used the seedling pathogenicity inspection method to evaluate the efficiency of the fungicide Flutriafol treatment in preventing disease progression. The fungicide (in a final concentration of 10 $\mathrm{mg} / \mathrm{ml}$ active ingredient) was added with the watering to a colony disk agar inoculating seedlings of the susceptible maize Jubilee cv. All other conditions were the same as described above. Each treatment included 10 replications, three of which were selected arbitrarily for the DNA-based assay.

\section{Results}

\subsection{Pathogenicity on Maize}

As previously reported [9], the fungus spreads slowly during the first five weeks after corn germination. In commercial fields, when growing susceptible maize cultivars such as Jubilee, the first symptoms of late wilt disease usually appeared 50 - 60 d after sowing (Israel Northern R \& D, Migal-Galilee Research Institute, Kiryat Shmona, Israel, unpublished data [8]), shortly before the tasseling stage. The disease progression symptoms recorded by us match the data in the literature. By flowering (anthesis at 9 - 10 weeks), the disease is distributed throughout the stalk [20]. The first apparent symptom is a moderately rapid wilting of affected plants [23] when the lower leaves turn a dull green then lose their color and become dry as if suffering from dehydration (Figure 1(a)). Indeed, at this stage, many vessels are blocked with hyphae and a dark gum-like substance [20]. Supporting that, a longitudinal section of diseased maize plants (Figure $\mathbf{1}(\mathrm{b})$ ) reveals a concentration of yellowbrown hue in the internodes. The ascending of drying out upwards includes color alteration of the vascular bundles to a yellow-brown hue (Figures 1(b) and (c)) and then the appearance of red-brown stripes on the lower internodes [8]. Later, symptoms include parenchyma tissue breakdown (Figure 1(c)) that may cause the plant to collapse.

Eventually, the lower stem dries out (particularly at the internodes), shrinks and becomes hollow (Figure 1(c) $[12,21])$. Vascular occlusion appears to be the principle cause of late wilt symptom development. The kernels are infected by the systemic infection (Figure 1(d)). In severe cases, no cobs are formed. If seeds appear, they are shrunken and undeveloped [6]. Indeed, in a field experiment conducted on the Kibbutz Naot Mordechai maize field in the spring-summer of 2008 [9], Jubilee cobs were poorly developed and more than two-thirds (73\%) were class B (cob weight less than 250 g) (Figure 1(e)). H. maydis is a soil-borne vascular wilt pathogen. Unlike other

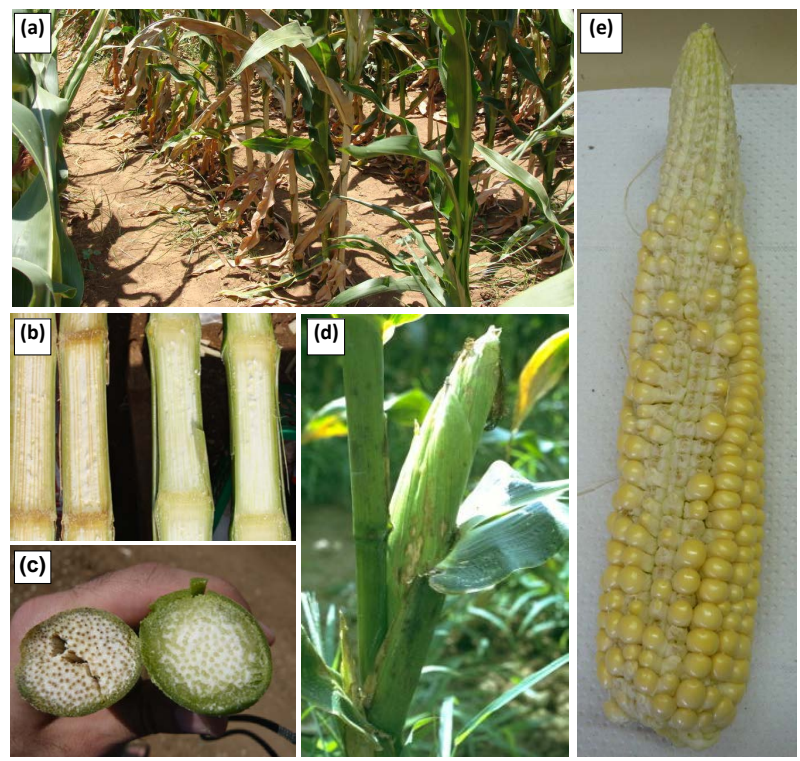

Figure 1. Late wilt disease symptoms in Israel. (a) Late wilt diseased field symptoms: drying out ascends upwards in the plant, including leaf yellowing and dehydration, and color alteration of the lower stem and internode. Wilted Jubilee cv. plants photographed in the southern area (No. 10) of a maize field in Kibbutz Naot Mordechai in the Hula Valley (Upper Galilee, northern Israel) $75 \mathrm{~d}$ after sowing (28/6/08, 15 days after fertilization). (b) Color alteration of the vascular bundles to a yellow-brown hue seen in the longitudinal section of a stream from a late wilt diseased maize plant (left) and a healthy maize plant (right). (c) Cross-section of the same plants. (d) Late wilt infected maize cob leaves. Photograph was taken 17 days after fertilization (7/7/09, 77 days after sowing). (e) Late wilt diseased poorly developed maize cob. images were photographed by Ran Drori and Tsafrir Weinberg. 
common maize pathogens such as $C$. heterostophus (used here as a positive control), the Israeli $H$. maydis isolates are incapable of penetrating the maize seedlings through the leaves (Figure 2). This is in agreement with the Egyptians' characterization report of isolates [20]. Injuring the leaves enhanced the ability of $C$. heterostophus to penetrate the host but didn't enable $H$. maydis to attack the host plant.

\subsection{Fungicide Efficiency Agar Plate Assay}

We investigated whether $H$. maydis can grow efficiently on agar plates containing fungicide concentrations of 0.1 $\mathrm{mg} / \mathrm{L}$ and more, active ingredient. Using an in vitro fungicide sensitivity assay, we identified four fungicides that at high dosages (10 $\mathrm{mg} / \mathrm{L}$ active ingredient) significantly $\left(\mathrm{P}<1 \times 10^{-5}\right)$ inhibited mycelial growth compared to the control from five days after inoculation (Table 1, Figure 3). The inhibitory effect in agar plates of all four fungicides generally increased with an increase in concentration (data presented only for the $10 \mathrm{mg} / \mathrm{L}$ dosages active ingredient). Prochloraz and the mixture of $26.7 \%$ Boscalid and $6.7 \%$ Pyraclostrobin were the most effective against $H$. maydis in comparison to Flutriafol and Azoxystrobin (Figure 3). A subsequent experiment carried out with these fungicides showed that at low concentrations ( $1 \mathrm{mg} / \mathrm{L}$ active ingredient instead of $10 \mathrm{mg} / \mathrm{L}$ ), the Flutriafol compound is more efficient than the other fungicides tested above (Figure 4). This experiment also included the application of a mixture of two efficient fungicides in order to identify synergistic effects (Figure 4). Although no such effect was observed, a potential antifungal compound comprised of two different control mechanisms is important in preventing the fungicides' resistance.

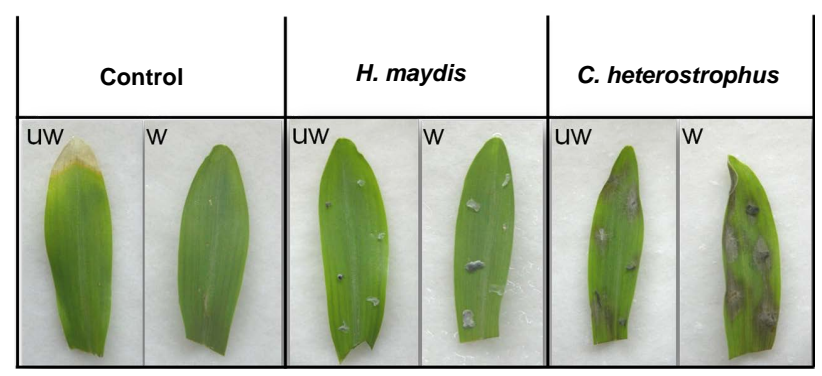

Figure 2. Detached leaves pathogenicity assay. Inoculation of intact leaves was done by placing Harpophora maydis 12-mm-diameter culture agar pieces on the surface of 17day-old maize seedlings first leaves. Photographs were taken three days after incubation in a moist petri dish at $28^{\circ} \mathrm{C}$ under continuous white light in a growth incubator. Control - untreated leaves, UW-unwounded leaves, W-wounded leaves, injured by immediately piercing them with a sterile wooden toothpick before laying the culture agar piece at the injured location.
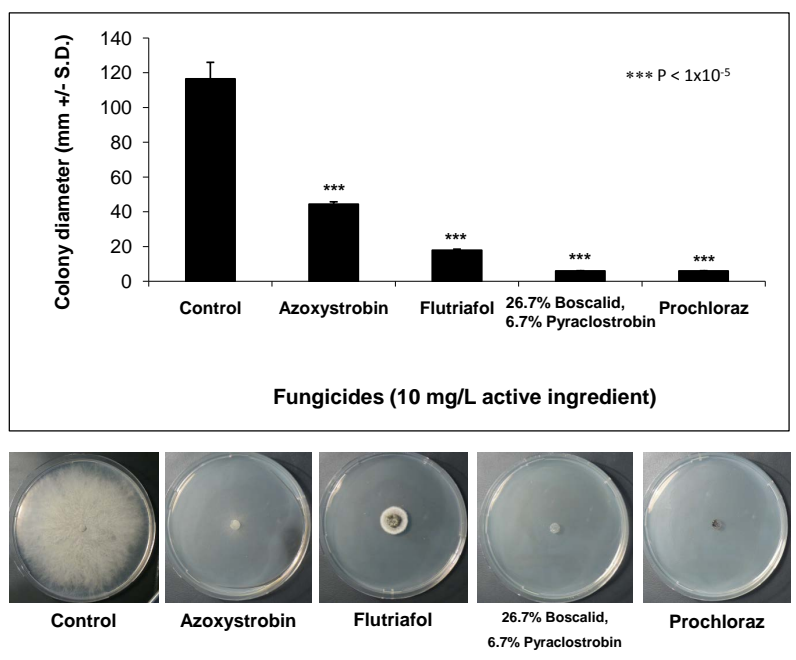

Figure 3. Fungicide efficiency agar plate assay. The fungicides were evaluated at a rate of $10 \mathrm{mg} / \mathrm{L}$ active ingredient. Upper panel-inhibition of $\boldsymbol{H}$. maydis mycelial growth by selected fungicides was evaluated by measuring the increase in colony diameter five days after incubation at $28^{\circ} \mathrm{C}$ in the dark. Lower panel-photographs were taken on the same day. Control-potato dextrose agar plates without fungicide. Values are means of six replications. The in vitro evaluation included four technical-grade, commercial fungicides: Azoxystrobin (CAS no. 131860-33-8, Amistar $^{\circledR}, 250$ g/l, Makhteshim Agan, Airport City, Israel), Flutriafol (CAS no. 87676-93-5, 10 mg/ml, Hosen, Makhteshim Agan, Airport City, Israel), mixture of $26.7 \%$ Boscalid (CAS no. 18842585-6) and 6.7\% Pyraclostrobin (CAS No. 175013-18-0) (Signum W.G. ${ }^{\circledR}, 267$ g/l and 67 g/l respectively, Agan, Ashdod, Israel) and Prochloraz (CAS no. 68444-81-5, Sportec, 450 g/l, Merhav Agro Ltd., Herzliah Israel).

\subsection{Detached Root Pathogenicity Assay}

Assessing the fungicidal effect on the ability of $H$. maydis to infect detached roots was performed to evaluate the inhibitory effect when the fungus grows on its natural food source. All inoculated roots (Figure 5) had dark brown root infection threads (seen as dark filaments within the root) that were clearly distinguishable from the remaining healthy root. Control roots without fungicides (Figure 5) had more than double the length of infection threads at the apical cut ends after six days of incubation.

\subsection{Seedling Pathogenicity Assay}

Inoculation experiments (soil and seed) were performed in order to develop an effective way of infecting maize seedlings. This is important since a seedling pathogenicity assay may enable us to examine different fungicides and other treatments to locate resistant maize strains and to study the penetration and establishment of pathogenesis stages. After several preliminary experiments, an infection method based on colony agar disks or hyphae inocula (see Materials and Methods) was selected. It was 


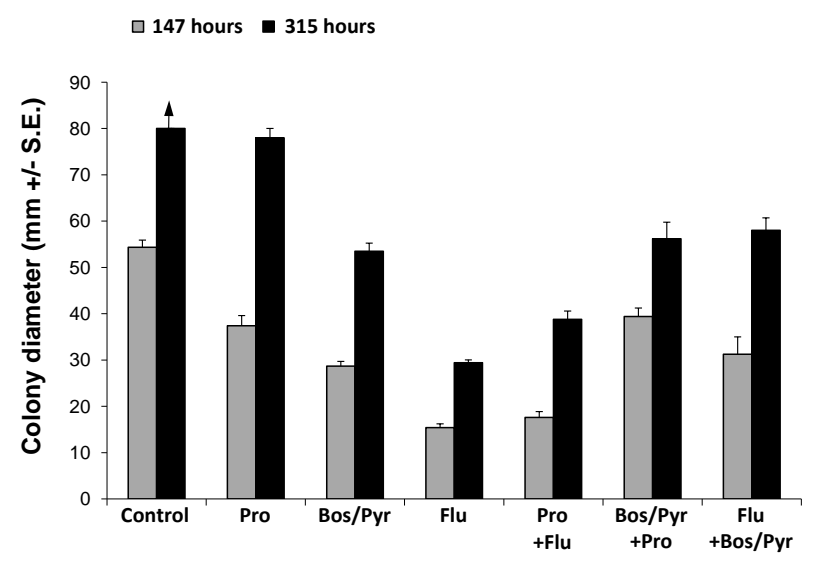

Figure 4. Colonies' radial growth under the combined influence of selected fungicides. The fungicides were evaluated at a rate of $1 \mathrm{mg} / \mathrm{L}$ active ingredient. In the synergism testing groups (combination of two different compounds), the final concentration of $1 \mathrm{mg} / \mathrm{L}$ was the sum of $0.5 \mathrm{mg} / \mathrm{L}$ of each of the two fungicides tested. Inhibition of $\mathrm{H}$. maydis mycelial growth was evaluated by measuring the increase in colony diameter 147 and 315 hours after incubation at $28^{\circ} \mathrm{C}$ in the dark. The colonies in the control treatment (potato dextrose agar plate without fungicide) reached the margins of the growth media plates before the second measurement and therefore the column is marked by an arrow pointing upwards. Abbreviations: Pro-Prochloraz, Bos/Pyr-mixture of $26.7 \%$ Boscalid and 6.7\% Pyraclostrobin and FluFlutriafol. Values represent the average of five replicates.

reported that plants become more resistant to infection as they mature, and 50-day-old plants were not susceptible to infection unless the roots were injured [20]; however, screening for infection occurs routinely by passing those most likely resistant to natural infection by injecting $H$. maydis into the $1^{\text {st }}$ or $2^{\text {nd }}$ stem node of 50-60-day-old plants $[6,7,29]$. Root injury predisposes plants to the disease [6,29]. Our attempts to increase the effect of inoculation in seedlings by injuring the roots (punching the root above the root cap once with a $30 \times 0.6 \mathrm{~mm}$ needle) or by injecting the pathogen spores suspension $(0.2 \mathrm{ml}$ sterile DDW containing $5 \times 10^{-3}$ spores/ml) directly into the lower part of the steam right above the ground did not result in any significant difference (data not shown). Early attempts at infecting the seedlings showed that at two weeks after inoculation (28 days after sowing), the pathogen was identified in the root and was more evident in the stem (data not shown). Extracting the DNA from the whole plant (root and shoot together, Figure 6(b)) instead of from the root and stem separately enabled us to improve the identification of the pathogen DNA. The DNA diagnosis identified the fungus in both the susceptible Jubilee cv. maize and the relatively resistant Royalty $\mathrm{cv}$. In the latter, the amount of pathogen DNA in the host tissues was reduced (Figure 6(b)), as was previously observed in naturally infected field plants [9].
Examining three-week-old infected seedlings reveals that only the roots of the plants were symptomatic (Figure 6(a)), while no symptoms were observed in the shoots. Average root length in the Jubilee cv. group was decreased in both infection modes (colony agar disks, and significantly in the hyphae inocula treatment) in comparison to untreated control plants. In the relatively resistant Royalty cv., the effect of fungal inoculation was less pronounced and observed only in the hyphae inocula treatment (Figure 6(a)).

The pathogen DNA was clearly identified in the infested seedlings (Figure 6(b)), in both infection methods. Since the pathogen DNA was more clearly pronounced in the susceptible Jubilee cv. maize infested seedlings (Figure 6(b)), this cultivar was chosen to demonstrate the ability of antifungal agent to suppress the fungal development. Applying the fungicide Flutriafol to the seedling of the susceptible Jubilee cv. maize irrigation suspension caused a reduction in pathogen DNA in the host tissues beneath the detection threshold (Figure 6(c)). This proved that the seedling pathogenicity assay is capable of identifying potential effective fungicides.

\section{Discussion}

This work demonstrates the use of new methods for detecting and tracking $H$. maydis and its interactions with the maize host plant under control conditions. In particular, we use these methods for assessing the ability of selected fungicides to suppress the pathogen development in vivo. The method of assaying the effect of fungicides on the pathogen in a series of trials starting in a petri dish plate assay, followed by detached root and resulting in a seedlings pathogenicity assay, using molecular and morphological approaches presented here should be addressed in a critical manner but it has several advantages. In the past, many attempts were made to eradicate the pathogen using chemical and biological methods [31-36]. Some fungicides tested worked well in pots but failed in field experiments [32]. For example, it was found that systemic fungicide Benomyl (methyl 1-(butylcarbamoyl) benzimidazol-2-ylcarbamate, CAS no. 17804-35-2) at 2.5 to $100 \mathrm{ppm}$ concentration completely inhibits late wilting disease in pots (seed treatment is not effective), but the application of $10 \mathrm{~kg}$ Benomyl $/ 4200 \mathrm{~m}^{2}$ in the field failed to prevent the disease [34]. In contrast, AbdEl-Rahim and colleagues (1982) found that the systemic Benylate fungicide (benzyl benzoate, CAS no. 120-51-4) applied four times at 15-day intervals $\left(10 \mathrm{~kg} / 4200 \mathrm{~m}^{2}\right)$ after sowing resulted in a $30 \%$ increase in crop yield [32].

Despite the inconsistency of the ability of in vitro plate assays and even pot plant assays in predicting results in the field, these preliminary steps are important in ruling out ineffective treatments and choosing the ones that 

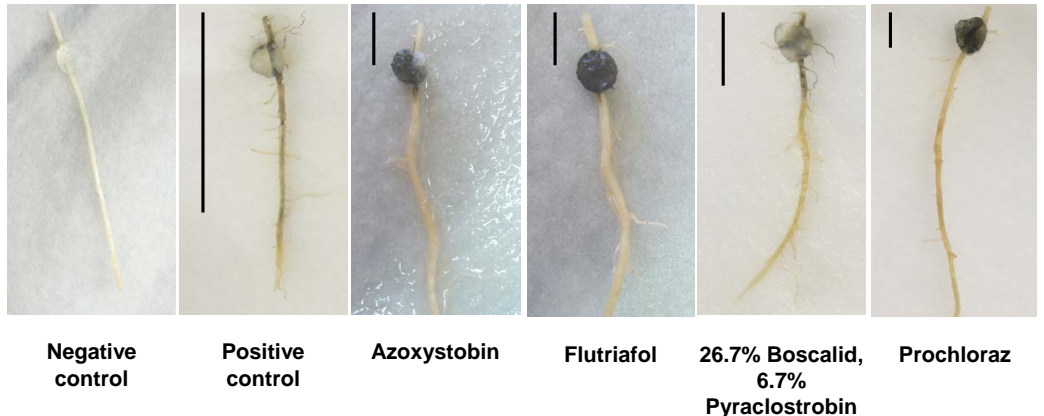

Figure 5. Detached root pathogenicity assay. The longest inner feeder roots were removed from potted 21-day-old maize seedlings (Jubilee cv.) inoculated by placing a 6-mm-diameter culture agar disk taken from the growing edge of a 4-6-day-old fungal colony (grown at $28^{\circ} \mathrm{C}$ in the dark) $2 \mathrm{~cm}$ away from its cut end. The inoculated roots were then incubated in moist petri dishes at $28^{\circ} \mathrm{C}$ in the dark for six days. The progression of the pathogen infection thread inside the xylem tissue of each root (seen as a dark filament within the root) was evaluated qualitatively after six days of inoculation and marked in the photograph by a black line positioned at the left of each root. Negative control-root treated by placing a 6-mm-diameter growth media agar disk from a sterile noninoculated plate. Positive control—root inoculated with $\mathrm{H}$. maydis without fungicides.

(a)

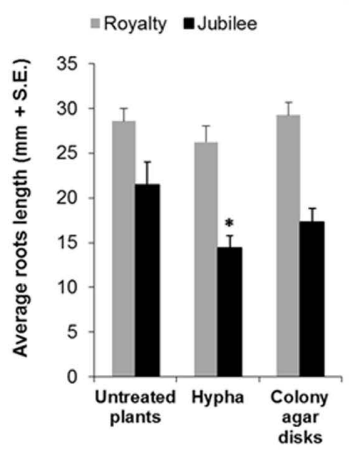

(b)

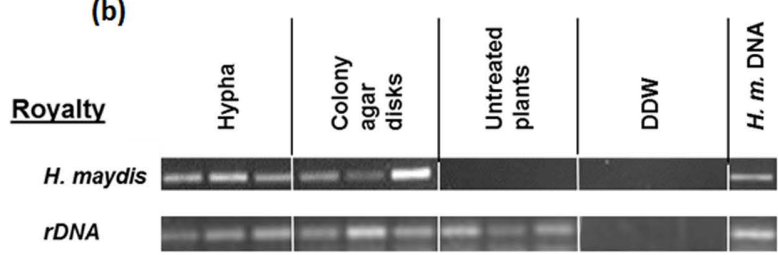

Jubilee

H. maydis

rDNA

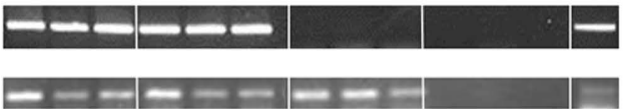

(c)

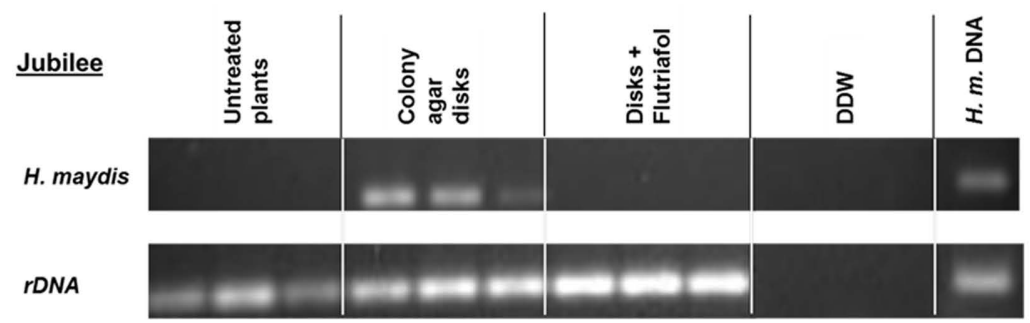

Figure 6. Seedlings pathogenicity assay. Seedlings of both the susceptible maize Jubilee cv. and the relatively resistant Royalty cv. were grown to the four-leaf stage (22 days after planting) in plastic seedling pot trays. Seedling inoculation was done with the sowing four days after germination by adding three 6-mm-diameter agar disks from 6-day-old $\mathrm{H}$. maydis (Colony agar disks) or $10 \mathrm{ml}$ of $0.5 \mathrm{gr} / \mathrm{ml}$ mycelium suspension (Hypha) to the upper parts of the roots $(2-5 \mathrm{~cm}$ beneath the ground surface). Each treatment included 10 independent replications. (a) Root length was determined as the average length of the longest root of each plant in $\mathbf{1 0}$ independent replicates of each cultivar. Untreated plants were used here as a control group. Asterisk represent significant $(p=0.03)$ difference from the control. Values represent the average of five replicates. (b) In order to identify the fungus in the host plant tissues, three plants (22 days old) from each treatment group were sampled arbitrarily and analyzed (root, stem and leaves together) for the presence of the pathogen using a PCR-based method. H. maydis-amplified H. maydis-specific oligonucleotide, rDNA-amplified 18S eukaryotic ribosomal DNA. Controls: DDWdouble-distilled water used as a template in the PCR mixture to ensure the absence of DNA contamination; and $H$. maydis DNA used as positive control. (c) Evaluation of the efficiency of the fungicide Flutriafol treatment in preventing disease progression. The fungicide (in a final concentration of $10 \mathrm{mg} / \mathrm{ml}$ active ingredient) was added with the watering to colony disk agar inoculated seedlings of the susceptible maize Jubilee cv. (Disks + Flutriafol). All other conditions were the same as described above. Each treatment included 10 replications, three of which were selected arbitrarily for the DNA-based assay. 
would most likely succeed. In addition, the root pathogenicity assay and use of the PCR-based approach to detect fungus in host tissues presented here are new methods that may enhance the prediction ability of preliminary trials before the application of fungicides in the field. Continued development of these preliminary steps is necessary. A scientific program aimed at developing disease control cannot be based solely on field trials during the growing season due to the long waiting time until results are received, the great efforts involved in such experiments and the changing environmental conditions causing inconsistency in the results. The seedlings pathogenicity assay in a controlled environment is important in order to study the early stages of the disease, to develop new resistance maize strains and to evaluate new ways of controlling the disease.

At present, the most economically effective management of late wilt is through the development of genetically resistant corn lines [27]. However, little information is available in the literature on the pathogen's development in apparently asymptomatic maize varieties. Zeller et al. [19] identified four AFLP primer pairs that could be used as markers to determine the distribution of $H$. maydis lineages and to identify new lineages in field populations. Here, we used this $H$. maydis-unique nucleotide sequence, which proved earlier to be species-specific [17], as a diagnostic tool. As previously described [9], the pathogen spreads in moderately resistant Royalty cv. plant tissues, roots, leaves and stalks in a similar way to the pathogenesis in the sensitive maize Jubilee cv. However, the amount of fungal DNA detected in the tissues of plants was lower than that detected in the susceptible plants. In addition, the spread of the fungus through Royalty cv. host tissues is apparently delayed in comparison to the sensitive maize Jubilee cv. Nevertheless, this variety displayed no disease symptoms and grew well, even in heavily infested soils [9]. The relatively lesser amounts of pathogen DNA in Royalty imply that it does not become well established. Our seedling pathogenicity assay supports these observations (Figures 6(a) and (b)).

It is unclear how the host has restricted the ability of the pathogen to grow and induce disease symptoms. Since $H$. maydis is capable of undergoing pathogenic variations $[18,43]$, new virulent strains could develop and breeding for resistance will remain a continuous process. To exemplify this importance, a virulent lineage exists in Egypt that is a threat to some resistant maize cultivars [18], while in Israel the relatively resistant maize cultivar, Royalty, which has become the leading maize cultivar since the late disease outburst, started to show wilting symptoms in the summer of 2010 and caused significant economic damage when a disease outburst caused its collapse in Beit She'an (Jezreel Valley, Lower Galilee region in Israel) maize fields in the summer of 2013 (Israel
Northern R \& D, Migal—Galilee Research Institute, Kiryat Shmona, Israel, unpublished data). According to the same logic, the need to identify new effective compounds against the late wilt causing agent is urgent and requires uninterrupted efforts.

\section{Conclusion}

In conclusion, this work reports on maize late wilt disease symptoms caused by the fungus $H$. maydis and the subsequent severe economic loss incurred in Israel. A series of assay carried out under controlled conditions was used to identify the pathogen spread in an in vitro plate assay and in the host tissues (detached roots and seedlings) under the control of selected fungicides. Four of the tested antifungal compounds proved to be efficient against $H$. maydis under all conditions tested. The PCR-based assay exemplifies the ability of one of them, Flutriafol, to reduce the pathogen DNA in the host tissues. This approach of assaying the pathogen using molecular and morphological methods could be generalized to other plant pathogens.

\section{Acknowledgements}

We would like to thank Ran Drori (Migal - Galilee Research Institute, Israel) and Tsafrir Weinberg (Galilee Seeds, Research and Development, 1989, LTD, Israel) for their helpful advices. We also like to thank Inbal Mazal, Maayan Shair, and Meytal Kfir (Tel-Hai College, Israel) for their technical assistance. This work was supported by a research grant from the Israel Plant Council, Ministry of Agriculture and a research grant from the Jewish National Fund (Keren Kayemeth LeIsrael).

\section{REFERENCES}

[1] S. H. Michail, M. S. Abou-Elseoud and M. S. Nour Eldin, "Seed Health Testing of Corn for Cephalosporium maydis," Acta Phytopathologica et Entomologica Hungarica Vol. 34, 1999, pp. 35-42.

[2] A. S. Samra, K. A. Sabet and M. F. Abdel-Rahim, "Effect of Soil Conditions and Cultural Practices on Infection with Stalk Rots,” U.A.R. Ministry of Agric. Government Printing Offices, Cairo, 1966.

[3] W. Gams, "Cephalosporium-Artige Schimmelpilze (Hyphomycetes),” G. Fischer, Stuttgart, 1971. http://dx.doi.org/10.1002/jobm.19730130317

[4] H. A. El-Shafey and L. E. Claflin, "Late Wilt," APS Press, St. Paul, Mn, 1999.

[5] K. A. Sabet, A. S. Samra, M. K. Hingorani and I. M. Mansour, "Stalk and Root Rots of Maize in the United Arab Republic,” FAO Plant Protection Bulletin, Vol. 9, 1961, pp. 121-125.

[6] M. M. Payak, S. Lal, J. Lilaramani and B. L. Renfro, "Cephalosporium maydis-A New Threat to Maize in India,” 
Indian Phytopathology, Vol. 23, 1970, pp. 562-569.

[7] S. Pecsi and L. Nemeth, "Appearance of Cephalosporium maydis Samra Sabet and Hingorani in Hungary," Mededelingen Faculteit Landbouwkundige en Toegepaste Biologische Wetenschappen, Universiteit Gent, Vol. 63, 1998, pp. 873-877.

[8] R. Drori, "Involvement of Harpophora maydis in Late Wilt Disease of Sweet Corn: Characterization of the Disease Cycle and Identifying Means of Control,” Ms.C. Thesis, the Robert H. Smith Faculty of Agricultural, Food and Enviromental Quality Sciences, Hebrew University of Jerusalem, Rehovot, 2010.

[9] R. Drori, A. Sharon, D. Goldberg, O. Rabinovitz, M. Levy and O. Degani, "Molecular Diagnosis for Harpophora maydis, the Cause of Maize Late Wilt in Israel," Phytopathologia Mediterranea, Vol. 52, 2012, pp. 16-29. http://www.fupress.net/index.php/pm/article/view/10824

[10] M. L. Molinero-Ruiz, J. M. Melero-Vara and A. Mateos, "Cephalosporium maydis, the Cause of Late Wilt in Maize, a Pathogen New to Portugal and Spain,” Plant Disease, Vol. 94, 2011, pp. 379-379. http://dx.doi.org/10.1094/PDIS-94-3-0379A

[11] L. Johal, D. M. Huber and R. Martyn, "Late Wilt of Corn (Maize) Pathway Analysis: Intentional Introduction of $\mathrm{Ce}$ phalosporium maydis," Pathways Analysis for the Introduction to the US of Plant Pathogens of Economic Importance, United States Department of Agriculture, Animal and Plant Health Inspection Service, Technical Report No. 503025, 2004.

[12] K. A. Sabet, A. S. Samra and N. A. Dawood, "Combined Infection with Stalk-Rot Fungi,” In: A. S. Samra and K. A. Sabet, Eds., Investigations on Stalk-Rot Disease of Maize in U.A.R., Ministry of Agriculture, Government Printing Offices, Cairo, 1966, pp. 195-204.

[13] A. F. Sahab, A. R. Osman, N. K. Soleman and M. S. Mikhail, "Studies on Root-Rot of Lupin in Egypt and Its Control,” Egyptian Journal of Phytopathology, Vol. 17, 1985, pp. 23-35.

[14] A. A. Saleh and J. F. Leslie, "Cephalosporium maydis Is a Distinct Species in the Gaeumannomyces-Harpophora Species Complex,” Mycologia, Vol. 96, 2004, pp. 12941305. http://dx.doi.org/10.2307/3762146

[15] H. L. Warren, "Potential Disease Problems: Late Wilt of Maize,” Phytopathology, Vol. 73, 1983, p. 782.

[16] E. M. El-Assiuty, A. M. Ismael, K. A. Zeller and J. F. Leslie, "Relative Colonization Ability of Greenhouse-Grown Maize by Four Lineages of Cephalosporium maydis from Egypt,” Phytopathology, Vol. 89, 1999, S. 23.

[17] A. A. Saleh, K. A. Zeller, A. S. Ismael, Z. M. Fahmy, E. M. El-Assiuty and J. F. Leslie, “Amplified Fragment Length Polymorphism Diversity in Cephalosporium maydis from Egypt,” Phytopathology, Vol. 93, 2003, pp. 853-859. http://dx.doi.org/10.1094/PHYTO.2003.93.7.853

[18] K. A. Zeller, M. I. Abou-Serie, E. M. El-Assuity, Z. M. Fahmy, F. M. Bekheet and J. F. Leslie, "Relative Competitiveness and Virulence of Four Clonal Lineages of $\mathrm{Ce}$ phalosporium maydis from Egypt toward GreenhouseGrown Maize,” Plant Disease, Vol. 86, 2002, pp. 373378. http://dx.doi.org/10.1094/PDIS.2002.86.4.373
[19] K. A. Zeller, J. E. Jurgenson, E. M. El-Assiuty and J. F. Leslie, "Isozyme and Amplified Fragment Length Polymorphisms from Cephalosporium maydis in Egypt," Phytoparasitica, Vol. 28, 2000, pp. 121-130.

http://dx.doi.org/10.1007/BF02981741

[20] K. A. Sabet, A. M. Zaher, A. S. Samra and I. M. Mansour, "Pathogenic Behaviour of Cephalosporium maydis and $C$. acremonium," Annals of Applied Biology, Vol. 66, 1970, pp. 257-263.

http://dx.doi.org/10.1111/j.1744-7348.1970.tb06432.x

[21] A. S. Samra, K. A. Sabet and M. K. Hingorani, “A New Wilt Disease of Maize in Egypt," Plant Disease Reporter, Vol. 46, 1962, pp. 481-483.

[22] A. H. Shehata, "Gene Action Involved in the Manifestation of Late Wilt (Cephalosporium maydis) of Maize," Egyptian Journal of Genetics and Cytology, Vol. 5, No. 1, 1976, pp. 42-47.

[23] A. S. Samra, K. A. Sabet and M. K. Hingorani, "Late Wilt Disease of Maize Caused by Cephalosporium maydis," Phytopathology, Vol. 53, 1963, pp. 402-406.

[24] S. D. Singh and B. S. Siradhana, "Influence of Some Environmental Conditions on the Development of Late Wilt of Maize Induced by Cephalosporium maydis," Indian Journal of Mycology and Plant Pathology, Vol. 17, 1987, pp. 1-5.

[25] S. D. Singh and B. S. Siradhana, "Survival of Cephalosporium maydis, Incitant of Late Wilt of Maize," Indian Journal of Mycology and Plant Pathology, Vol. 17, 1987, pp. 83-85.

[26] S. E. D. Botros, M. S. Mohamed, A. M. El-Shabrawy and A. Abd-Elrakik, "Effect of Intercropping Maize with Certain Legumes on the Incidence of Maize Root and Stalk Rots," ASSIUT Journal of Agricultural Sciences, Vol. 21, 1990, pp. 155-170.

[27] H. A. El-Shafey, F. A. El-Shorbagy, I. I. Khalil and E. M. El-Assiuty, "Additional Sources of Resistance to the Late-Wilt Disease of Maize Caused by Cephalosporium maydis," Agricultural Research Review, Vol. 66, 1988, pp. 221-230.

[28] K. A. Sabet, A. S. Samra and I. M. Mansour, "Saprophytic Behaviour of Cephalosporium maydis and C. acremonium,” Annals of Applied Biology, Vol. 66, 1970, pp. 265271. http://dx.doi.org/10.1111/j.1744-7348.1970.tb06433.x

[29] S. D. Singh and B. S. Siradhana, "Date of Sowing in Relation to Late Wilt Disease of Maize," Indian Phytopathology, Vol. 41, 1988, pp. 489-491.

[30] S. D. Singh and B. S. Siradhana, "Effect of Macro and Micronutrients on the Development of Late Wilt of Maize Induced by Cephalosporium maydis," Summa Phytopathology, Vol. 16, 1990, pp. 140-145.

[31] M. S. Abdel-Hamid, M. F. Abdel-Momeim, H. A. ElShafey and S. T. El-Deeb, "Biological Control of LateWilt Disease of Maize Caused by Cephalosporium maydis,” Agricultural Research Review, Vol. 59, 1981, pp. 253-260.

[32] M. F. Abd-el-Rahim, K. A. Sabet, H. A. El-Shafey and E. M. El-Assiuty, "Chemical Control of the Late-Wilt Disease of Maize Caused by Cephalosporium maydis,” Ag- 
ricultural Research Review, Vol. 60, 1982, pp. 31-49.

[33] A. A. El-Mehalowy, N. M. Hassanein, H. M. Khater, E. A. Daram El-Din and Y. A. Youssef, "Influence of Maize Root Colonization by Rhizosphere actinomycetes and Yeast Fungi on Plant Growth and on the Biological Control of Late Wilt Disease," International Journal of Agriculture and Biology, Vol. 6, 2004, pp. 599-605.

[34] K. A. Sabet, A. S. Samra and M. F. Abdel-Rahim, "Systemic Action of Benomyl against Late-Wilt Disease of Maize,” Annals of Applied Biology, Vol. 71, 1972, pp. 211218. http://dx.doi.org/10.1111/j.1744-7348.1972.tb05084.x

[35] E. Satyanarayana and H. Begum, "Relative Efficacy of Fungicides (Seed Dressers) and Irrigation Schedule for the Control of Late Wilt of Maize,” Current ResearchUniversity of Agricultural Sciences (Bangalore), Vol. 25, 1996, pp. 59-60.

[36] S. D. Singh and B. S. Siradhana, "Chemical Control of Late Wilt of Maize Induced by Cephalosporium maydis," Indian Journal of Mycology and Plant Pathology, Vol. 19, 1989, pp. 121-122.

[37] S. Muhammad and N. A. Amusa, "In Vitro Inhibition of Growth of Some Seedling Blight Inducing Pathogens by Compost-Inhabiting Microbes," African Journal of Biotechnology, Vol. 2, 2003, pp. 161-164.

[38] E. M. El-Assiuty, A. A. El-Hamahmy and A. Y. El-Shar- kawy, "Bacillus subtilis, Pseudomonas fluorescens and Verticillium tricorpus as Biological Agents against LateWilt of Maize,” Egyptian Journal of Applied Sciences, Vol. 6, 1991, pp. 824-829.

[39] O. Degani, R. Maor, R. Hadar, A. Sharon and B. A. Horwitz, "Host Physiology and Pathogenic Variation of Cochliobolus heterostrophus Strains with Mutations in the G Protein Alpha Subunit, CGA1,” Applied and Environmental Microbiology, Vol. 70, No. 8, 2004, pp. 50055009. http://dx.doi.org/10.1128/AEM.70.8.5005-5009.2004

[40] J. Leach, B. R. Lang and O. C. Yoder, "Methods for Selection of Mutants and in Vitro Culture of Cochliobolus heterostrophus,” Microbiology, Vol. 128, 1982, pp. 17191729. http://dx.doi.org/10.1099/00221287-128-8-1719

[41] M. Fromont-Racine, B. Senger, C. Saveanu and F. Fasiolo, "Ribosome Assembly in Eukaryotes," Gene, Vol. 313, 2003, pp. 17-42. http://dx.doi.org/10.1016/S0378-1119(03)00629-2

[42] D. Smith, A. Hooker and S. Lim, "Physiologic Races of Helminthosporium maydis,” Plant Disease Reporter, Vol. 54, 1970, pp. 819-822.

[43] E. M. El-Assiuty, H. A. El-Shafey, A.-S. Ismael and Z. M. Fahmy, "Pathogenic Variation in Cephalosporium maydis," Phytopathology, Vol. 88, 1988, S. 25. 